\title{
Pemberdayaan Wanita Di Desa Banjar Timur Gapura Sumenep Melalui Pelatihan Pembuatan Biskuit Ekstrak Daun Kelor Untuk Meminimalisir Resiko Balita Gizi Buruk
}

\author{
Zakiyah Yasin ${ }^{1 *}$, Eka Meiri Kurniyati, Emdat Suprayitno \\ ${ }_{1,2,3}$ Fakultas Ilmu Kesehatan Universitas Wiraraja \\ *Email: zakiyafik@wiraraja.ac.id
}

\begin{abstract}
Background: One indicator of the success of community welfare is poor nutrition. The impact of malnutrition is extensive on the governance structure, especially starting from the economy, intelligence, and quality, which affects children's future. Of course, to reduce poor nutritional status, the latest and modern breakthroughs are needed, one of which is using biscuits to fulfill additional food for toddlers. This is very interesting because toddlers tend to like snacks such as biscuits. The development of biscuit production is increasingly varied and diverse by adding other ingredients. One of them is the addition of moringa oleifera leaf extract, which improves children's nutrition. Methods: Oservational and analytical methods by Socialization, Training, and Mentoring. Results: Activity participants can understand and make Moringa leaf extract biscuits. Participants can also develop the effects of the training to provide health benefits for children and have economic value. Conclusion: empowering community groups (pokmas) in East Banjar village to develop moringa oleifera as a productive economy and healthy food for all communities, especially toddlers.
\end{abstract}

Keywords: biscuits, moringa oleifera extract, toddlers, poor nutrition;

\section{PENDAHULUAN}

Banjar Timur adalah desa yang berada di kecamatan Gapura, Kabupaten Sumenep, Banjar Timur yang sebagian besar masyarakatnya adalah petani dan buruh. Hal ini menjadi salah satu factor penyebab banyaknya balita yang mengalami gizi buruk. Observasi awal dengan menggunakan metode Tanya jawab tidak terstruktur dapat disimpulkan bahwa gizi buruk yang diderita balita di Desa Banjar Timur karena kurangnya pengetahuan warga terkait kesehatan, makanan bergizi dan kebersihan lingkungan. Layanan kesehatan yang dimiliki Desa Pamolokan (Polindes) kurang bisa member pemahaman kepada masyarakat terkait kesehatan, makanan bergizi dan kebersihan lingkungan.

Kesadaran masyarakat juga memiliki pengaruh besar terhadap kesehatan, makanan bergizi dan kebersihan lingkungan sehingga berdampak kepada tumbuh kembang anak (Suprayitno \& Yasin, 2021). Sebagian anak di desa Banjar Timur mengalami gizi buruk yang disebabkan oleh ketidak tahuan orang tua mengenai makanan bergizi. Keadaan balita yang mengalami gizi buruk dianggap biasa dan akan sembuh dengan sendirinya manakala sudah menginjak dewasa, sehingga gizi buruk tidaklah dianggap suatu masalah serius yang akan mengakibatkan pertumbuhan dan perkembangan balita lamban (Sugeng et al., 2019)

Gizi buruk salah satu indikator keberhasilan kesejahteraan masyarakat. Dampak gizi buruk terhadap masyarakat sangat luas mulai dari ekonomi, kecerdasan dan kualitas, yang berefek pada masa depan anak (Qolbi et al., 2020). Kejadian Gizi Buruk pada anak khususnya balita dikarenakan kurang memperhatikan status gizi dan pengelolahan makanannya (Wardita et al., 2021). Status gizi memiliki pengaruh yang sangat besar dalam mewujudkan sumber daya manusia yang berkualitas di masa yang akan datang. Permasalahan status gizi pada balita masih jadi pekerjaan rumah dan 
tantangan, yang memang dipengaruhi banyak faktor, seperti faktor ekonomi, sosial budaya, pendidikan, dan faktor lingkungan (Siallagan et al., 2021).

Untuk mengurangi status gizi buruk, tentunya perlu terobosan yang terkini dan modern, salah satunya menggunakan biscuit dalam memenuhi makanan tambahan bagi balita. Hal ini sangat menarik karena balita memiliki kecendrungan suka makanan ringan seperti biscuit. Pengembangan prosuksi biscuit semakin bervariasi dan beraneka ragam dengan menambahkan bahan yang lain. Salah satunya dengan penambahan ekstrak daun ekstrak moringa oleifera yang salah satu fungsinya adalah memperbaiki nutrisi anak (Rahayu \& Nurindahsari, 2018).

\section{TINJAUAN PUSTAKA}

Kelor (Moringa oleifera) tumbuh hingga \pm 1000 dpl di dataran rendah dan dataran tinggi. Kelor banyak ditanam sebagai tanaman pagar atau pagar tanaman di pekarangan dan ladang. Daun kelor bisa dipanen setelah tanaman tumbuh hingga 1,5 hingga 2 meter, yang biasanya memakan waktu 3 hingga 6 bulan. Namun, budidaya intensif untuk mendapatkan daun membuat ketinggian kelor di bawah $1 \mathrm{~m}$. Pemanenan dilakukan dengan cara memanen batang daun dari cabang atau memotongnya setinggi 20-40 cm di atas permukaan tanah (Irwan, 2020).

Tanaman kelor kaya akan nutrisi berupa protein, -karoten, vitamin C, dan mineral terutama zat besi dan kalsium. Tanaman kelor banyak mengandung senyawa aktif berupa antioksidan terutama pada bagian daunnya. Daun kelor mengandung flavonoid, sterol, triterpenoid, alkaloid, saponin dan fenol (Sugianto, 2016).

Definisi Gizi BurukGizi buruk adalah keadaan gizi berdasarkan indeks massa tubuh (BB/U) menurut usia yang sesuai dengan gizi kurang (Kemenkes RI, 2011), dan menurut Kementerian Kesehatan RI tahun 2008, ) <3 SD dan/atau kejadian pada anakanak menurut tanda-tanda klinis marasmus, kwashiorkor dan marasmus kswashiorkor (Depkes RI, 2019).

\section{DESAIN PENELITIAN}

Desain pengabdian pada masyarakat ini menggunakan Teknik Sosialisasi pada tanggal 11 Juni 2021 di Desa Banjar Timur Kecamatan Gapura Kab. Sumenep. Yang dugunakan untuk memperkenalkan program yang akan dilaksanakan dalam kegiatan PKM ini, dengan harapan peserta PKM dapat menerima apa yang disampaikan oleh pemateri. Pada kegiatan PKM ini, sosialisasi menggunakan laflet, power point dan modul pembuatan biskuit.

Setelah menyelesaikan sosialisasi, maka peserta diberi pelatihan membuat biskuit ekstrak daun kelor menggunakan tata cara yang telah dipelajari pada modul. Peserta kemudian didampingi selama proses pembelajaran sehingga di akhir pengabdian pada masyarakat ini tujuan dapat di capai dengan baik dengan adanya pemantuan atau evaluasi dan kuesioner pengetahuan yang disebarkan $\mathrm{k}$ peserta pendampingan .

\section{HASIL PENELITIAN}

Hasil kegiatan pemberdayaan perempuan sebanyak 30 orang dengan pelatihan pembuatan biskuit sari daun kelor di Desa Banjar Gapura Timur Kabupaten Sumep. Berdasarkan kegiatan yang dilakukan dalam bentuk ceramah, diskusi, tanya jawab, dan pelatihan, terdapat beberapa hasil evaluasi kegiatan, antara lain kerja sama, unggul dan kooperatif. Dibuktikan dengan ikut serta dalam penyusunan atau penetapan titik konsultasi. 
Peserta acara dapat mempelajari cara membuat kue kering dengan ekstrak daun kelor, terbukti dengan mengetahui cara membuat kue kering dengan ekstrak daun kelor. Peserta latihan atau pelatihan dapat memahami dan membuat cookies ekstrak daun kelor hasil evaluasi ini di lihat setelah dilakukan program pendampingan pebuatan.

\section{PEMBAHASAN}

Pemberdayaan wanita melalui pelatihan pembuatan biskuit ekstrak daun kelor merupakan inovasi dalam mengelola dan memanfaatkan bahan dasar yang mudah di dapat namun memiliki manfaat yang sangat besar dalam membantu pertumbuhan balita dan menjauhkan resiko gizi buruk pada balita.

Kegiatan ini sesuai dengan penelitian tahun 2015 oleh Giuhartini dalam Journal of Moringa tentang pengaruh cookies dan bahan makanan campuran kelor terhadap berat badan dan tinggi badan pada bayi gizi buruk di ruang kerja Puskesmas Kalumpang, Ternate, 2015. Asupan energi dan protein pada anak gizi buruk selama 30 hari pengenalan PMT BCM Moringa mempengaruhi pertambahan berat badan bayi dan tuberkulosis. Hasil analisis konsumsi energi dan protein untuk MT dan TB sebelum dan sesudah introduksi BMC Moringa PMT diperoleh nilai MT rata-rata 10,29 kg dan setelahnya $11 \mathrm{~kg}$. Pertambahan berat badan bayi $0,5 \mathrm{~kg}$ sebanyak 5 bayi, pertambahan berat badan $0,61 \mathrm{~kg}$ sebanyak 4 bayi, pertambahan berat badan $>1 \mathrm{~kg}$ sebanyak 2 bayi, dan rerata TB sebelum PMT BMC Kelor adalah 88,12 cm 00,5 cm. 6 bayi, 0,61 cm untuk 1 anak, $1 \mathrm{~cm}$ untuk 4 bayi (Juhartini, 2016).

Pertumbuhan dan perkembangan pada balita terasa sangat cepat sehingga perlu asupan gizi yang sangat tinggi. Apabila balita tidak mendapatkan penanganan yang benar, maka permasalahan gizi akan mudah terjadi. Oleh sebab itu, balita harus diberikan penanganan yang tepat khususnya dalam pemenuhan kebutuhan pangan dan gizinya. Penelitian yang dilakukan oleh Zaki Irwan, dkk pada tahun 2019, menyatakan bahwa tepung daun kelor dapat dijadikan alternative dalam peningkatan BB anak karena selain mengandung $\mathrm{Fe}$ dan protein tinggi yang dapat meningkatkan anti bodi anak sehingga lebih kebal penyakit dan mengandung anti oksidan yang dapat mengikat radikal bebas (Irwan et al., 2020).

Kesamaan hasil dari pengabdian ini dengan penelitian sebelumnya menggambarkan bahwa biskuit daun kelor memiliki kandungan gizi dan vitamin yang dibutuhkan balita sehingga dapat meminilisir gizi buruk balita. Pada kegiatan pemberdayaan ini, peserta pelatihan sangat antusias dan memiliki semangat dalam kegiatan sosialisai, pelatihan dan pemberdayaan dalam pembuatan biskuit ekstrak daun kelor, peserta termotivasi dengan adanya program ini karena dapat membantu peserta baik dari segi pengetahuan, ekonomi, dan kesehatan.

Tentu saja, upaya pemberdayaan ini memiliki unsur inspiratif dan daya pikat. Kekuatan pendorong di balik pelatihan ini adalah mitra sangat aktif dalam kegiatan pekerjaan umum. Hal ini terbukti sejak awal sosialisasi. Wilayah Banjar, Gapura, lurah timur Kabupaten Sumenep dapat mendukung kegiatan tersebut dan menjalankan kegiatan PKM dengan lancar.

Kegiatan sosialisasi yang dipandu oleh kelompok masyarakat (POKMAS) di desa Banjar Timur dan sedang mempersiapkan tempat untuk acara yang dapat didukung secara langsung melalui gotong royong, namun kendala dalam kegiatan PKM ini membuat peserta tidak memahami pentingnya daun kelor. bahwa ada kesulitan. Namun, TIM PKM tetap semangat dan tekun dalam menyadari pentingnya daun kelor dan inovasi dalam produksi. 


\section{KESIMPULAN DAN SARAN}

Kegiatan PKM yang telah dilakukan di Desa Banjar Timur Kec. Gapura Kabupaten Sumenep tentang pelatihan pembuatan biskuit ekstrak daun kelor untuk meminimalisir resiko balita gizi buruk memiliki potensi keberlanjutan yang sangat baik dan adanya dukungan dari berbagai pihak, potensi tersebut diantaranya. Peserta pelatihan dapat membuat biscuit ekstrak daun kelor untuk dikonsumsi sendiri maupun di pasarkan. Sehingga dapat membantu perekonomian masyarakat.

Dengan adanya pelatihan ini peserta bisa dengan mandiri membuat biskuit daun kelor sebagai makanan tambahan bagi diri sendiri maupun orang lain khususnya balita yang terindikasi menderita gizi buruk, biskuit ini juga bisa dipasarkan sehingga bernilai ekonomis dengan harapan dapat membantu perekonomian masyarakat. Peserta pelatihan dapat membudidayakan Pohon Kelor Sehingga bernilai ekonomis.

Daun kelor juga perlu di budidayakan dengan tujuan menghindari kurangnya stok daun kelor di tengah-tengah masyarakat. Peserta pelatihan dapat mengurangi tingkat balita gizi buruk di Desa Banjar Timur dengan mengkonsumsi biskuit daun kelor. Apabila masyarakat memiliki komitmen dan mendalami tentang pelatihan ini, tidak menutup kemungkinan balita yang berada di Desa Banjar Timur memiliki tingkat kesehatan dan gizi yang baik.

\section{DAFTAR RUJUKAN}

Depkes RI, D. R. I. (2019). Panduan Penyelenggaraan pemberian makanan tambahan pemulihan bagi Balita gizi kurang. STIKES PERINTIS.

Irwan, Z. (2020). Kandungan Zat Gizi Daun Kelor (Moringa Oleifera) Berdasarkan Metode Pengeringan. Jurnal Kesehatan Manarang, 6(1), 69-77.

Irwan, Z., Salim, A., \& Adam, A. (2020). Pemberian cookies tepung daun dan biji kelor terhadap berat badan dan status gizi anak balita di wilayah kerja Puskesmas Tampa Padang. AcTion: Aceh Nutrition Journal, 5(1), 45-54.

Juhartini, J. (2016). PENGARUH PEMBERIAN MAKANAN TAMBAHAN BISKUIT DAN BAHAN MAKANAN CAMPURAN KELOR TERHADAP BERAT BADAN DAN HEMOGLOBINStudi Pada Balita Dengan Status Gizi Kurus Di Wilayah Kerja Puskesmas Kalumpang Kota Ternate Tahun 2015. Hospital Majapahit (Jurnal Ilmiah Kesehatan Politeknik Kesehatan Majapahit Mojokerto), $8(2)$.

Qolbi, P. A., Munawaroh, M., \& Jayatmi, I. (2020). Hubungan Status Gizi Pola Makan dan Peran Keluarga terhadap. Jurnal Ilmiah Kebidanan Indonesia, 10(4), 167175.

Rahayu, T. B., \& Nurindahsari, Y. A. W. (2018). Peningkatan status gizi balita melalui pemberian daun kelor (Moringa oleifera).

Siallagan, D., Rusiana, D., Susilawati, E., Tinggi, S., Kesehatan, I., Tinggi, S., Kesehatan, I., \& Info, A. (2021). Determinan Stunting di Puskesmas Wilayah Kabupaten. Indonesian Journal of Midwifery, 4(1), 1-11. 
Sugeng, H. M., Tarigan, R., \& Sari, N. M. (2019). Gambaran Tumbuh Kembang Anak pada Periode Emas Usia 0-24 Bulan di Posyandu Wilayah Kecamatan Jatinangor. Jurnal Sistem Kesehatan, 4(3).

Sugianto, A. K. (2016). Kandungan gizi daun kelor (Moringa oleifera) berdasarkan posisi daun dan suhu penyeduhan.

Suprayitno, E., \& Yasin, Z. (2021). Pendampingan Peran Keluarga terhadap Tumbuh Kembang Anak pada Masa Pandemi Covid-19 Di RA Al Hilal Pamolokan. Jurnal Empathy Pengabdian Kepada Masyarakat, 63-68.

Wardita, Y., Suprayitno, E., \& Kurniyati, E. M. (2021). Determinan Kejadian Stunting pada Balita. Journal Of Health Science (Jurnal Ilmu Kesehatan), 6(1), 7-12. 